\title{
Performance Measurement of Indonesian Shariah Bank Using Balanced Scorecard Approach
}

\author{
Euis Bandawaty \\ Faculty of Economics and Business, As Syafi' 'iyah Islamic University, Indonesia \\ Ph.D student of Faculty of Economics and Business, Indonesia Education University, Indonesia \\ Agus Rahayu Lili Adi Wibowo \\ Faculty of Economics and Business, Indonesia Education University, Indonesia
}

\begin{abstract}
At present there are still many Sharia Bank companies in Indonesia that measure their performance based only on a financial perspective. In fact, to deal with the increasingly complex business environment as it is today, performance measurement based only on a financial perspective is no longer sufficient because it has several weaknesses. Therefore Sharia Bank needs to implement the concept of comprehensive performance measurement, namely the Balanced Scorecard, which consists of four perspectives; financial, consumer, internal business processes, as well as learning and growth. The purpose of this study is to evaluate the performance of Bank Muamalat Indonesia by using the Balanced Scorecard. This research was conducted in 2019 by conducting interviews and distributing questionnaires to customers of Bank Muamalat Indonesia operating in East Jakarta, Jakarta Province, Indonesia. The bank's performance is measured based on financial perspectives (four indicators), consumers (six indicators), internal business processes (three indicators), and learning and growth (three indicators). The results of the analysis showed that the company's performance from a financial perspective gained an achievement level of $90 \%$. This achievement can be said to be very good, because the company's performance is nearing the set target. Furthermore, this study found that achieving company performance in the customer's perspective was $97 \%$; achievement of company performance in the perspective of internal business processes is $72 \%$; and the achievement of company performance from a learning and growth perspective is $99 \%$. The results of the study have implications that Bank Muamalat Indonesia needs to make various efforts to improve company performance, especially in the perspective of internal business processes to balance financial and non-financial performance in order to realize its mission and vision.
\end{abstract}

Keywords: performance measurement, Indonesian sharia bank, balanced scorecard

DOI: $10.7176 / \mathrm{EJBM} / 12-17-01$

Publication date:June 30th 2020

\section{Introduction}

Sharia banks are banks that carry out business activities based on Sharia principles, namely the rules of agreement based on Islamic law between banks and other parties for depositing funds and/or financing business activities, or other activities that are declared in accordance with Sharia. Sharia banks, or commonly called Islamic banks in other countries, are different from conventional banks in general. The main difference lies in the operating basis used. If conventional banks operate based on interest, Islamic banks operate based on profit sharing, plus buying and selling and leasing. This is based on the belief that interest contains elements of usury that are prohibited by Islam (Aslam et al., 2016).

In the Islamic view, in the interest system, there is an element of injustice because the owner of the fund requires the borrower to pay more than the borrowed regardless of whether the borrower makes a profit or suffers losses. On the other hand, the profit sharing system used by Islamic banks is a system where borrowers and lenders share risks and benefits in accordance with the agreement. In this case no party is harmed by another party. Furthermore, when viewed from an economic perspective, Islamic banks can also be defined as an intermediary institution that streams public investment optimally (with the obligation of zakat and prohibition of usury) that is productive (with a ban on gambling), and is carried out according to values, ethics, morals, and Islamic principles (Sari et al., 2016).

In Indonesia, Islamic banks have emerged since the early 1990s with the establishment of Bank Muamalat Indonesia. At present, the company has 76 branch offices throughout Indonesia and one overseas branch. Islamic banks are slowly able to meet the needs of the public who want banking services that are in accordance with the Islamic Shariah principles they adhere to, especially those relating to the prohibition of usury practices, nonproductive speculative activities similar to gambling, obscurity, and violations of the principle of fairness in transactions, and the necessity of channeling financing and investments to ethical and halal business activities in a Shariah manner (Mariyono, 2013).

However, the rapid development of Islamic banks has only been felt since the reform era in the late 1990s, after the government and Bank Indonesia gave great commitments and took various policies to develop Islamic 
banks, especially since the change in banking laws with Law No. 10 of 3 1998. The various policies not only involved expanding the number of offices and operations of Islamic banks to increase the supply side, but also involved developing public understanding and awareness to increase the demand side. The rapid development has been particularly noted since the issuance of Bank Indonesia regulations granting permits for opening new sharia banks and permits for conventional banks to establish a sharia business unit (Tampubolon, 2015).

The growth of the banking business today is experiencing developments marked by the establishment of various banks. Thus, companies must be able to compete with other banks and provide competitive advantages and show improved performance. Therefore, a good management strategy is needed and relevant to the current conditions. One important part of strategic management is performance evaluation which is useful to provide feedback to the company to take corrective action. So far, the company's performance evaluation has not been comprehensive in all aspects of the company's business activities where the performance evaluation is carried out only on financial and employee performance. Evaluation of employee performance is carried out on the achievement of work goals, work methods, and personal characteristics of employees (Heavey and Murphy, 2012; Hudson et al., 2001).

In the context of strategic management, the key activity that provides feedback from a whole set of management actions is performance measurement. Performance measurement is an assessment or comparison between the realization of targets and targets set. This is done in order to provide feedback and corrective action if the company's performance or achievements are not satisfactory. So far, the performance measurements carried out by banks in general only rely on the financial aspect. The performance measurement system is not enough to reflect the performance conditions of a company or organization as a whole. In addition, performance measurements that only rely on the financial aspect are less relevant to current performance needs. This is caused by the dynamics of the fast moving competitive environment, so it does not inform what efforts need to be taken now and in the future to improve company performance (Atkinson, 2006; Jusoh et al., 2007).

At present, it is realized that the measurement of financial performance used by many companies to measure executive performance is no longer sufficient, so a Balanced Scorecard concept was developed. The concept of balanced scorecard performance measurement has features in terms of comprehensive measurement coverage, because in addition to considering financial performance, the concept also considers non-financial performance. In addition, the balanced scorecard measures not only the final activity (out come) but also the activities that determine the final result (driver). In general, there are four types of business performance measured in a balanced scorecard, namely the financial perspective, customer perspective, internal business process perspective, and learning and growth perspective (Kaplan and Norton, 1992, 1996).

This research focuses on four perspectives, namely financial perspective, customer perspective, business process perspective, and learning and growth perspective. Financial perspective is intended to analyze whether the strategy, strategic objectives, strategic initiatives and their implementation are able to contribute in generating profits for the company or not. This will be seen by using financial analysis tools, by analyzing the company's financial statements for a certain period. The customer perspective is intended to analyze the extent to which a product or service is said to have value for consumers. The product or service will increasingly have value if the benefits are close to or exceeding what is expected by consumers. The business process perspective is aimed at analyzing the ways companies identify important internal business processes. Because the internal process has the values that customers want and will be able to provide the returns expected by shareholders in the form of profits or company profits. Learning and growth perspectives are aimed at analyzing whether the company has a goal to drive to become a learning organization that at the same time encourages its growth. Because thus the development of the company will be seen, it can be seen from how the company conducts its business activities.

This study aims to evaluate the company's strategy map with the BSC approach, identify the design of the company's performance measurement system with the BSC approach, and analyze the company's performance measurement with the BSC approach. The results of this study can provide input for information for company management in evaluating company performance, assisting company management in observing and evaluating the development of the company to match the current development of the business world, and improving company performance in the future. will come, by knowing the company's shortcomings through research that will be conducted.

\section{Literature Review}

\subsection{General Overview of Indonesian Sharia Banking}

According to Republic of Indonesia Law Number 10 of 1998, banking is a business entity that collects funds from the public in the form of deposits and distributes them to the public in the form of credit and or other forms in order to improve the lives of many people. Based on this law, the banking structure in Indonesia consists of Commercial Banks and Rural Credit Banks. The main difference between commercial banks and Rural Credit Banks is in terms of their operational activities. In this case, commercial banks can create demand deposits while Bank Perkreditan Rakyat cannot create demand deposits that have limited scope and operational activities. 
Furthermore, commercial banks can carry out bank business activities both conventionally and based on sharia principles. While the principle of People's Credit Bank activities is limited to only being able to conduct conventional bank business activities or based on sharia principles (Aslam et al., 2016; Tampubolon, 2015).

Furthermore, according to RI Law Number 21 Year 2008, Islamic Banks are banks that carry out their business activities based on Sharia Principles. By type, Sharia Banks consist of Sharia Commercial Banks and Sharia People Financing Banks. Sharia Commercial Bank is a Sharia Bank, which in its activities provides services in payment traffic. Whereas the Sharia People Financing Bank is a Sharia Bank, which in its activities does not provide services in payment traffic. Specifically, Islamic banks are intermediary institutions and financial service providers that work based on Islamic ethics and value systems, especially those that are free from interest, free from speculative non-productive activities such as gambling, free from things that are unclear and doubtful, principled in justice, and only finance halal business activities. Islamic banks are often equated with banks without interest. Bank without interest is a narrower concept than a Sharia bank, when a number of instruments or operations are free of interest. Islamic banks, in addition to avoiding interest, also actively participate in achieving the goals and objectives of an Islamic economy oriented to social welfare. In its operations, Islamic banks follow Islamic rules and norms, as mentioned in the above definition, namely free of interest, free of non-productive speculative activities such as gambling, free of unclear and doubtful matters, free from things that are damaged or illegitimate, and only finance halal business activities (Fitriasari, 2012; iman, and widodo, 2016).

Islamic banks have two main roles, namely as a business entity and social agency. As a business entity, Islamic banks have several functions, namely as investment managers, investors, and services. As an investment manager, Islamic banks collect funds from investors / customers with Islamic principles. As an investor, Islamic banks channel funds through investment activities with the principle of profit sharing, buying and selling, or leasing. As a provider of banking services, Islamic banks provide financial services, non-financial services, and agency services. Financial services include, but are not limited to principles such as mandating, bank guarantees, debt transfer, debt or mortgage guarantees, benevolent loans for bailouts, and buying and selling of foreign currencies. Nonfinancial services in the form of safe deposit boxes and agency services. Meanwhile, as a social body, Islamic banks have functions as managers of social funds for the collection and distribution of zakat, infaq, and sadaqah funds, as well as the distribution of benevolent loans (Mariyono, 2013; Sari et al., 2016).

\subsection{Performance measurement}

Performance is a general term used for some or all actions or activities of an organization in a period, along with references to a number of standards such as past or projected costs, a basis of efficiency, accountability or management accountability and the like. Thus, a business activity can be said to have a good rating if it is based on the basis of performance appraisal standards (Hudson et al., 2001). Performance appraisal is basically a human activity in achieving organizational goals. Jusoh et al. (2007) defines performance appraisal as a periodic determinant of the operational effectiveness of an organization, parts of the organization, and employees based on predetermined goals, standards and criteria. Because organizations are basically operated by human resources, performance appraisal is actually an assessment of human behavior in carrying out the roles they play in the organization. Every organization expects performance that contributes to making the organization a superior institution in its class. If the success of an organization to become a superior institution is determined by various factors, then these factors can be used as a measure of personal success. Thus, a performance appraisal is needed that can be used as a basis for designing an award system so that personnel produce performance that is in line with the performance expected by the organization (Manville, 2007).

Traditionally, the measurement of performance commonly used is a measure of financial performance. This performance measurement is easy to do so that the measured performance of personnel is only related to finance. However, financial measures cannot illustrate the causes that make changes in wealth created by organizations and focus more on mobilizing organizational resources for short-term goals (Sainaghi et al., 2013). Referring to Sim and Koh (2001), financial measures that are commonly used are financial ratios which include liquidity ratios that measure a company's ability to meet short-term obligations when due, leverage ratios that measure to what extent the company financed by debt, activity ratio which measures how effective management is aimed at profits generated from sales and investment of the company, growth ratio that measures the ability of a company to maintain its economic position in economic and industrial growth, and ratio valuations that measure management's ability to create market value that exceeds investment cost expenditures.

According to Hudson et al. (2001), performance measurement using ratios as above has limitations namely this ratio is prepared based on accounting data and this data is influenced by different interpretations and can even be the result of manipulation, if the company uses years different fiscal or if the seasonal factor is an important influence it will have an effect on the ratio ratios, analysis must be very careful in determining the merits of a ratio in forming a comprehensive assessment of the company based on a series of financial ratios, and ratios that are in line with industry averages do not provide certainty that the company is running normally and has good management. Meanwhile, according to Kaplan and Norton (1997), weaknesses in performance measurement that 
focus on financial performance, namely the inability to measure the performance of intangible assets and intellectual assets (human resources) of the company and financial performance is only able to tell a little about the company's past and is not able to fully guide the company towards better.

\subsection{Balanced Scorecard}

Balance Scorecard is a scorecard that is used to measure performance by taking into account the balance between the financial and non-financial side, between the long and short term, and involves internal and external factors. Balance scorecard is a contemporary management tool that meets the needs of companies in dealing with a very competitive business environment. These conditions require companies to be able to build competitive advantage through distinctive capability, be able to build sustainable and update the journey map to realize the company's future, and able to direct and focus the capabilities of the commitment of all personnel in building the future company (Kaplan and Norton, 1996). The Balanced Scorecard is an integrated performance measurement model that is derived from a corporate strategy that supports the overall corporate strategy. The Balanced Scorecard provides a way to communicate a company's strategy to managers throughout the organization. The Balanced Scorecard also shows how companies perfect their financial performance (Kaplan and Norton, 1992).

According to Kaplan and Norton (1997), the Balanced Scorecard is a valuation method that includes four perspectives to measure company performance, namely the financial perspective, customer perspective, internal business process perspective and learning and growth perspective. The Balanced Scorecard emphasizes that financial and non-financial measurements must be part of the information for all employees at all levels for the organization. The objectives and measurements in the Balanced Scorecard are not only a combination of existing financial and non-financial measures, but also based on the mission and strategy of a business unit. The mission and strategy must be translated into more tangible goals and measurements. The Balanced Scorecard can be used to improve an organization's ability to multiply the financial performance on an ongoing basis

2.3.1 Financial Perspectives

In the Balanced Scorecard financial performance remains a concern, because financial measures are an overview and the economic consequences that occur caused by the decisions and economics that are taken (Wong et al., 2009). Financial performance measures indicate whether strategies, strategic objectives, strategic initiatives and their implementation are able to contribute in generating profits for the company. Kaplan and Norton (2001) suggest that financial perspectives act as a focus for strategic goals and measures of all perspectives in the Balanced Scorecard. In this case, the measurement of financial performance can consider the stages of the business life cycle consisting of growth, sustain and harvest stages.

According to Kaplan (2012), the growth stage is the initial stage of the company's life cycle where the company has a product or service that actually has the best growth potential. At the growth stage, a company might operate with negative cash flow with a low rate of return on capital. The yardstick used at this stage is the level of revenue or sales growth in the targeted market segment. The sustain stage is the second stage where the company is still investing and reinvesting by hinting at the best rate of return. At the harvest stage, the company no longer makes investments except for the maintenance and repair of facilities that it already has. The benchmark at this stage is to maximize cash flow into the company. The financial perspective is still used, because financial measures are very important in providing a summary of the consequences of economic actions that have been taken.

2.3.2 Consumer perspective

A product or service is said to have value for consumers if the benefits received by consumers are relatively higher than the sacrifices incurred by consumers to get the products and services. The product or service will increasingly have value if the benefits are close to or exceeding what is expected by consumers. According to Kaplan and Norton (1996), companies are expected to be able to make a market segmentation and determine the target market that is most likely to be targeted in accordance with the capabilities of the company's resources and long-term plans.

In the customer perspective, managers identify customers and market segments where the business unit competes and various performance measures for businesses in the target segment. This perspective usually consists of customer satisfaction, customer retention, acquisition of new customers, customer profitability and market share in the target segment. In the customer's perspective, it is measured in two types, namely the customer core with a measurement component consisting of market share, customer retention, customer acquisition, customer satisfaction and customer profitability. Whereas measurement and customer value propositions are performance triggers found in core value propositions based on product / service attributes, customer relationships and image and relationship (Kaplan and Norton, 1996).

2.3.3 Internal business process perspective

Internal business perspectives can be defined as a corporate value creation activities, which are strung into a single value that starts from the process of acquiring raw materials to the delivery of finished products to consumers (Atkinson, 2006; Zahoor, and Sahaf, 2018). It can also be said that as a process, parts of one another will be interconnected. Managers must focus their attention on internal business processes that determine customer 
satisfaction in company performance from a customer perspective. The performance from this perspective is obtained from the internal business performance process held by the company. Companies must choose the processes and competencies that are superior and determine the measures to assess the performance of these processes and competencies.

According to Kaplan and Norton (1996), identification of internal business processes is carried out in advance to get the right size in the perspective of internal business processes. In general the internal business processes consist of innovation, operations and after sales service. The innovation process is carried out by identifying customer needs and creating products or services that are needed. The operation process is intended to create and deliver products or services. Activities in this process are divided into two parts, namely the process of making products and the process of delivering products to customers. Performance measurements related to the operation process are time, quality and cost. The after sales service process is a service process for the customer after the sale of the product or service is carried out. Activities that occur at this stage are handling warranty and repairing damaged and returned goods, as well as processing customer payments. Furthermore, it needs to be emphasized that organizations that are not only oriented to sales and profits, but also must be responsible for the conditions of the surrounding environment (Ratnasingam, 2009).

2.3.4 Growth and learning perspective

The learning process and growth are based on human resource factors, organizational systems and procedures. Included in this perspective is employee training and corporate culture related to individual and organizational improvement (Chavan, 2009). According to Kaplan and Norton (1996), the perspective of learning and growth comes from three principles, namely the ability of workers, the ability of information systems, and motivation, empowerment and alignment. The fewer workers owned by the company, the company can provide workers with more appropriate access to information to further improve efficiency in achieving company goals. Benchmarks that can be used are the level of employee satisfaction, the level of employee turnover, the amount of company income per employee and the added value of each employee. The ability of the information system is determined by the level of information availability, the level of accuracy of the information and the time period required to obtain the information. Furthermore, to increase employee motivation, companies need to create an organizational climate that is able to create information itself and encourage employee initiatives. This aspect of success can be seen from the number of suggestions submitted by employees, the number of suggestions implemented and the level of the employee's ability to know the vision and mission carried by the company (Heavey and Murphy, 2012).

\section{Research Methodology}

\subsection{Research design}

Bank Muamalat Indonesia (BMI) requires the right strategy to achieve its goals. Therefore, BMI needs to apply good management in the stages of planning or strategy formulation, the stage of strategy implementation, and the strategy evaluation stage. These three stages are important in strategic management. In this study, researchers conducted interviews with internal BMIs operating in the East Jakarta area to review the vision, mission, goals and strategies, and to evaluate the condition of the company's development. After that the design of the performance measurement system is carried out at the BMI with the Balanced Scorecard approach. The vision, mission, goals and strategies set by the company are translated into strategic goals based on four perspectives of the Balanced Scorecard, namely financial, customer, internal business process, and learning and growth perspectives. The next step is to determine the relevant target size for each perspective. The target size consists of outcome measures and measures of triggers that are relevant to the objectives of each perspective. The measurement results are then identified and analyzed, so it can be seen which aspects are less supportive of the achievement of the company's vision, mission and objectives, so that later improvements can be taken for further company development.

\subsection{Data collection}

This research was conducted at PT. BMI operating in the area of East Jakarta, Jakarta Province, Indonesia. This research was conducted in July to December 2019. Types of data used for this study include qualitative and quantitative data. Data collection is done by conducting direct interviews with three managers and two senior company employees who have contributed in formulating the strategy. This interview was conducted to obtain data on targets, weighting, objectives and strategic measures that support the design of the Balanced Scorecard. In addition, this study also uses questionnaires to collect data related to learning and growth perspectives and customer perspectives. In this case, the respondents involved were 12 employees and 74 customers of PT. BMI. Specifically, the questionnaire was used to obtain data related to job satisfaction and employee motivation, and customer satisfaction.

\subsection{Data Analysis Methods}

After the formulation of the strategy is carried out, then the defined strategy is spelled out in four Balanced 
Scorecard perspectives to set strategic goals, measures and strategic initiatives based on each perspective by taking into account the vision, mission and objectives of BMI. The four perspectives of the Balanced Scorecard are financial perspectives, customers, internal business processes, and learning and growth. In this case, there are two measures that need to be determined to measure the success of achieving the strategy, namely the outcome measure and the size of the performance trigger. The success of achieving strategic goals is indicated by certain measures called outcome measures. Meanwhile, to achieve the size of the results required performance triggers.

This study uses the AHP method to determine the weight or level of importance of BMI to each of the Balanced Scorecard perspectives, strategic goals and strategic measures. Weighting is done so that performance measurements provide a more detailed indication and are directly related to BMI. The more important a perspective, target and outcome measure are for BMI, the greater the weight is given. Determination of the importance weight value from each perspective along with strategic objectives and main outcome measures in order to produce scores to compare the level of importance to each other using the pairwise comparison method.

This study uses customer satisfaction analysis to evaluate the achievement of strategic objectives from the customer's perspective. BMI must be able to provide quality services to its customers in order to have an advantage compared to its competitors. Measuring customer satisfaction provides benefits for banks in order to evaluate the company's position and performance. BMI service quality is evaluated in five dimensions, namely the dimensions of reliability, responsiveness, assurance, empathy, and tangibility.

\section{Results and Discussion}

\subsection{Identification of BMI's strategic objectives}

$\mathrm{BMI}$, as one of the Sharia banks in Indonesia, has a vision to become a leading bank in Islamic financing. The image given by BMI as a pioneer in providing housing credit gives more value to customers' trust in the bank. Whereas BMI's mission is to provide superior services in housing finance, related industries, increase competitive advantage through innovation in product development, services and the latest technology-based strategic network, prepare and develop high quality, professional, and high integrity human capital, implement appropriate banking management with the principle of prudence and good corporate governance to increase shareholder value and care for the interests of the community and its environment. Based on the vision and mission applied, it can be reduced to strategic objectives in four BSC perspectives, namely financial, customer, internal business process and learning and growth perspectives.

The determination of strategic objectives is aimed at achieving the company's vision, mission and goals in operational activities. This achievement requires a measure as an indicator of whether or not the desired target is achieved. There are two measures to measure strategic success, namely outcome measures and measures of drivers. Outcome measures are the strategic objectives that companies generally apply. The outcome measures are used as benchmarks for the success of achieving these goals. In achieving the expected results, it is necessary to measure performance drivers. Outcome measures without performance driving factors will not be able to communicate how the results are achieved. Whereas performance measures without outcome measures cause companies to focus only on short-term improvements without regard to long-term improvements in business. Benchmarks must be in accordance with the company's strategic objectives. Strategic goals set at each perspective must be able to be a benchmark that is able to measure the extent to which strategic objectives are achieved. The strategic goals achieved are an assessment of the operational implementation and the vision and mission set by the company. Table 1 shows the performance measures for achieving strategic objectives for BMI.

\subsection{BSC Strategic Map}

The strategy map is a set of strategic goals consisting of the four BSC perspectives covering financial, customer, internal business process and learning and growth perspectives. Strategic objectives are elaborated from the four BSC perspectives to describe the relationship between each perspective. Coordination flow is carried out from top to bottom as a result of the translation of vision, mission and strategy into BSC's strategic objectives which are more operational in nature; while the implementation is carried out simultaneously from the bottom to the top. It also illustrates the relationship and cause and effect between the perspective of BSC in BMI.

Employee satisfaction and motivation as well as professionalism are important parts for the creation of excellent service reliability, which includes transaction time, complaint handling time and queue waiting time. While on the reliability of technology and information, the company is trying to provide the best service, one of which is by providing ATM machines to facilitate customer transactions. Reliable achievement from the perspective of internal business processes greatly affects the achievement of customer perspectives, including increasing satisfaction of housing and customer credit borrowers, deepening potential customers, increasing the number of customers, increasing the number of debtors, preserving customer loyalty and causing a better categorization of debtors. Strategic objectives on a customer's perspective that are met will enhance financial perspectives as an integral result of all other perspectives. This is due to the purpose of the BSC is to increase long- 
term financial excellence.

Achieving the company's vision and mission requires a target as the level of achievement expected in future performance improvement. The target is the basis for achievement as a sign of success in achieving strategic goals. Performance measurement in all four BSC perspectives requires a target for each indicator in a strategic goal. The performance targets are set by the central BMI office with a number of things that are adjusted to the conditions of the working area. Past performance is a reference in determining future targets that always lead to the company's continuous improvement. Setting targets are adjusted to the condition of the company relating to finance and operations.

\subsection{Weighting the BMI performance perspective}

BMI's vision and mission have been translated into strategic objectives. The next step is to formulate strategic objectives based on the BSC perspective. The formulation was carried out after being interviewed by four BMI managers and based on relevant internal data. Strategic targets that have been confirmed are then given weight to determine the effect of each perspective on the continuity of BMI performance. The results of the weighting will be a reflection of the value of each strategic goal which is the most influential from each BSC perspective. This hierarchical structure consists of four levels. The first level is the performance of BMI. The second level is the goal which is the translation of BMI's vision and mission into four BSC perspectives. The third level is the strategy that is more specific to the strategic objectives from the four BSC perspectives. The formulation of the BSC strategic objectives becomes a tangible outcome measure or benchmark occupies the fourth level in the form of an operational strategy.

Table 1. BMI's strategic objectives

\begin{tabular}{|c|c|c|c|}
\hline \multirow{2}{*}{ No. } & \multirow{2}{*}{ Strategic objectives } & \multicolumn{2}{|c|}{ Strategic measures } \\
\hline & & Outcome measure & Driver measure \\
\hline \multicolumn{4}{|c|}{ Financial perspective } \\
\hline 1. & Operational cost efficiency & Reduction in operational costs & $\begin{array}{l}\text { Effectiveness and efficiency of } \\
\text { the operating process }\end{array}$ \\
\hline \multirow[t]{2}{*}{2.} & \multirow[t]{2}{*}{ Increased acceptance } & Growth of third party funds & $\begin{array}{l}\text { Increased potential of customer } \\
\text { funds }\end{array}$ \\
\hline & & Market share growth & $\begin{array}{l}\text { Increased funds received by the } \\
\text { company }\end{array}$ \\
\hline 3. & Increase profits & Increase profit & $\begin{array}{l}\text { Growth in giving credit and } \\
\text { decrease in FDR }\end{array}$ \\
\hline 4. & Declining FDR & Decreasing FDR & $\begin{array}{l}\text { Decreasing the number of debtors } \\
\text { with collectibility 3-5 }\end{array}$ \\
\hline \multicolumn{4}{|c|}{ Customer perspective } \\
\hline 1. & $\begin{array}{l}\text { Increased customer } \\
\text { satisfaction }\end{array}$ & $\begin{array}{l}\text { Index of housing loan debtors } \\
\text { and customer satisfaction }\end{array}$ & Survey of customer satisfaction \\
\hline \multirow[t]{2}{*}{2.} & \multirow[t]{2}{*}{$\begin{array}{l}\text { Deepening of potential } \\
\text { customers }\end{array}$} & $\begin{array}{l}\text { Increasing the number of } \\
\text { superior fund products }\end{array}$ & $\begin{array}{l}\text { Increasing the number of } \\
\text { potential customers }\end{array}$ \\
\hline & & $\begin{array}{l}\text { Increased realization of superior } \\
\text { mortgage products }\end{array}$ & \\
\hline 3. & $\begin{array}{l}\text { Increasing the number of } \\
\text { customers }\end{array}$ & $\begin{array}{l}\text { Increasing the number of product } \\
\text { accounts for funds }\end{array}$ & $\begin{array}{l}\text { Increasing the number of new } \\
\text { customers }\end{array}$ \\
\hline 4. & $\begin{array}{l}\text { Increasing the number of } \\
\text { debtors }\end{array}$ & $\begin{array}{l}\text { Increasing the number of debtor } \\
\text { accounts }\end{array}$ & Increasing new debtors \\
\hline 5. & $\begin{array}{l}\text { Maintaining customer loyalty } \\
\text { Increasing }\end{array}$ & Griya Multi credit distribution & Increasing credit reuse \\
\hline 6. & Eligible debtor categorization & $\begin{array}{l}\text { Increased collectibility credit } 1 \\
\text { and } 2\end{array}$ & Decreased FDR \\
\hline \multicolumn{4}{|c|}{ Internal business process perspective } \\
\hline \multirow[t]{2}{*}{1.} & \multirow[t]{2}{*}{$\begin{array}{l}\text { Improving the quality of } \\
\text { services }\end{array}$} & Queuing efficiency & $\begin{array}{l}\text { Speed and accuracy of the } \\
\text { transaction process }\end{array}$ \\
\hline & & Improvement of service facilities & $\begin{array}{l}\text { Improvement of facilities and } \\
\text { infrastructure }\end{array}$ \\
\hline 2. & $\begin{array}{l}\text { Efficiency of operating } \\
\text { processes }\end{array}$ & Efficiency of transaction time & $\begin{array}{l}\text { The speed and accuracy of } \\
\text { transaction processing }\end{array}$ \\
\hline
\end{tabular}




\begin{tabular}{|c|l|l|l|}
\hline \multirow{2}{*}{ No. } & \multicolumn{1}{|c|}{ Strategic objectives } & \multicolumn{2}{|c|}{ Strategic measures } \\
\cline { 3 - 4 } & & \multicolumn{1}{|c|}{ Outcome measure } & \multicolumn{1}{c|}{ Driver measure } \\
\hline 3. & Increased reliability & $\begin{array}{l}\text { Efficiency and effectiveness in } \\
\text { handling complaints }\end{array}$ & $\begin{array}{l}\text { Speed and accuracy of service } \\
\text { excellence }\end{array}$ \\
\hline Learning and growth perspective & & $\begin{array}{l}\text { Employee job satisfaction } \\
\text { survey }\end{array}$ \\
\hline 1. & $\begin{array}{l}\text { Increased employee } \\
\text { satisfaction and motivation }\end{array}$ & Employee satisfaction index \\
\hline 2. & $\begin{array}{l}\text { Increased expertise and } \\
\text { experience }\end{array}$ & Number of training programs & $\begin{array}{l}\text { Increased employee } \\
\text { performance }\end{array}$ \\
\hline 3. & $\begin{array}{l}\text { Reliability of technology and } \\
\text { information }\end{array}$ & Number of computers online & Computerized process \\
\cline { 3 - 4 } & Number of network systems & \\
\hline
\end{tabular}

BMI performance can be evaluated based on measurements using the BSC method. The BSC is a comprehensive and comprehensive measure of company performance related to the four perspectives studied. Perspectives in the BSC are finance, customers, internal business processes and learning and growth. The four perspectives are interrelated and cause a causal relationship. This performance measurement is useful as a benchmark for the success of achieving the specified vision and mission. Therefore, this performance measurement is very influential on the decision makers to improve the performance of BMI in the following year.

To measure BMI performance using the BSC, weighting must be carried out on its four perspectives, strategic objectives and outcome measures. Weighting is done using the AHP method to combine the opinions of expert groups. This expert group consists of several individuals who have knowledge and experience in their fields, as well as knowing in depth the internal conditions of BMI. The more important a perspective, strategic objectives and outcome measures are, the greater the weight given. The determination of weights at the BSC is very useful in determining the final BMI performance score. The total weight given overall is $100 \%$.

BMI mapped quite diverse weights in all four perspectives. In this case, the financial perspective gets a weighting of $19 \%$. Financial perspective is an important part of the company, but this is not an absolute determinant that describes the condition of the company. Customer perspective gets a weighting of $36 \%$. The customer perspective is the most important part in the process of measuring BMI performance. The internal business process perspective weighs $24 \%$ and the learning and growth perspective weighs $21 \%$. Based on weighting data using AHP, it can be seen that BMI has determined to prioritize the value of customers with high scores supported by its internal business processes. While the learning and growth perspective illustrates BMI has paid attention to HR, innovation and technology. Financial perspective has the lowest score, illustrated that to achieve its objectives in achieving financial targets, BMI prioritizes performance significantly to stakeholders.

In terms of weighting the financial perspective, this study found that the efficiency of operational costs gained a weighting of 34\%; the reduction in FDR gained a weight of $28 \%$; an increase in profit gained a weight of $20 \%$; and an increase in revenue gained a weight of $18 \%$. The findings illustrate that BMI's main objective is not only to focus on increasing profits, but to focus more on community housing finance. Therefore, BMI seeks to improve operational cost efficiency so that banks maintain their productivity levels. In addition, the decline in FDR greatly affected the credibility of BMI as a leading bank in housing finance. The increase in revenue was more triggered by $68.16 \%$ market share growth compared to $31.84 \%$ DPK growth. Bank BMI as a state-owned company engaged in banking faces quite high competition with other similar banks, thus considering the growth of market share as a subperspective that has a higher weight than the growth of DPK.

From the customer's perspective, the categorization of debtors who deserves a weighting of $24 \%$; maintained customer loyalty gained a weight of $19 \%$; an increase in the number of customers gaining weight of $16 \%$; increased customer satisfaction gained a weight of $15 \%$; an increase in the number of debtors gained a weight of $14 \%$; and deepening potential customers get a weight of $12 \%$. The results indicate that BMI prioritizes the proper classification of debtors relating to the company's core business. Customer loyalty is considered as an important part of contributing to the company through Griya Multi credit distribution. Loyal customers describe these customers as having a high level of trust in the company. BMI needs to emphasize the importance of customer satisfaction in increasing customer value. Potential customer deepening is triggered by an increase in the number of superior fund products and an increase in the realization of mortgage products with an equivalent percentage.

The internal business process perspective consists of three indicators, namely improving service quality, operating process efficiency, and improving reliability. The results of the analysis show that improving the quality of services gained a weight of $44 \%$; the efficiency of the operating process gained a weight of $32 \%$; while increasing reliability gets a weight of $24 \%$. The improvement in service quality is triggered by two outcome measures, namely queuing efficiency and an increase in service facilities with an equivalent percentage. In accordance with its vision of becoming a leading bank in housing finance, BMI prioritizes good service to customers and debtors. 
The strategic target of learning and growth perspective consists of three indicators, namely increasing employee satisfaction and motivation, increasing expertise and experience, and information and technology reliability. In this case, increased employee satisfaction and motivation gained weigh of $46 \%$; increased expertise and experience gained weight of 33\%; while the reliability of technology and information gained a weight of $21 \%$. Further analysis shows that employee motivation is very important to support the level of employee job satisfaction. The amount of education and training and the level of employee participation have an equal weight. In addition, $\mathrm{BMI}$ is also concerned with the increasing number of online post office services and networking systems.

\subsection{Achievement of BMI performance}

The analysis shows that the performance of BMI from a financial perspective obtained an achievement level of $90 \%$. This achievement can be said to be very good, because the performance of BMI is almost close to the target set. The reduction in FDR obtained a good level of achievement. This is due to the success of BMI in controlling debtors in the collectibility level of 3-5 or the category of bad credit. The lowest level of achievement was found in market share growth, which was $67 \%$. The decline in market share is very likely caused by the emergence of several similar companies and trying to capture the BMI market by providing housing finance loans which are the core business of BMI. Efficiency of operational costs and TPF growth have a level of achievement that is higher than the predetermined target value. This means that the company is able to control the increase in operational costs and increase the number of new BMI customers. The increase in BMI profit was $81 \%$. This achievement is close to the target set, but the company must increase its productivity again to increase profitability in the future. Furthermore, the results of the analysis show that the achievement of BMI's performance from the customer's perspective has met the target. The result measure that obtained the highest achievement was an increase in the realization of a superior mortgage product.

Achieving the lowest BMI performance from the customer's perspective is on increasing the number of debtor accounts. The increase in the number of fund product accounts $(97 \%)$ was triggered by an increase in the number of customers. This shows the trust of customers towards BMI. The cooperation carried out by BMI with the world of education provides benefits for BMI in increasing the number of DPK, especially in savings products. The increase in Griya Multi credit distribution also surpassed the target. This value shows the level of loyalty of BMI customers by repeating credit withdrawals.

Furthermore, this study found that achieving BMI's performance targets from the perspective of internal business processes was $72 \%$. This BMI performance achievement is categorized as well. This achievement is supported by the achievement of targets from the outcome measures. The improvement in service quality is triggered by queuing efficiency and improvement in service facilities. Queue efficiency reached 74\% of the target set. This shows that the performance of BMI in queuing time efficiency is good, because the number of tellers and batches is sufficient in conducting customer transactions even in crowded conditions. Improved service facilities obtain a $60 \%$ achievement rate. This facility consists of a number of ATM machines and batches (teller limiting). However, the batch did not experience an increase due to BMI space limitations. The efficiency of operating time is triggered by the efficiency of transaction time with an achievement level of $71 \%$. This achievement shows BMI's performance in transaction time efficiency is good. Efficiency and effectiveness in handling complaints received an achievement rate of $83 \%$. This illustrates that the excellent service provided to customers in handling complaints is well.

Finally, this study found that the performance of BMI in the perspective of learning and growth achieved an achievement rate of $99 \%$. These results indicate that the performance of BMI in the perspective of learning and growth is very good. This achievement is supported by its strategic goals, namely increasing employee satisfaction and motivation, increasing expertise and experience, and increasing the reliability of technology and information. Increased employee satisfaction and motivation is driven by an employee satisfaction index with an achievement of $94 \%$ and an employee motivation index with an achievement level of $99 \%$. Achievements in both outcome measures illustrate that BMI employees have high motivation in their work supported by employee job satisfaction. Increased expertise and experience is supported by two outcome measures, namely the number of training and the level of employee participation. This shows that BMI is very concerned about improving quality and human resources as human capital, and is supported by employee participation in participating in the training.

\section{Conclusions}

The measurement of BMI performance using the BSC approach is able to provide financial and non financial performance measure. Therefore, BSC approach is able to increase BMI profits in the long run in the face of an increasingly competitive environment. Based on the total BSC score, it can be seen that the BMI achievement in 2019 is $93 \%$. This value indicates that the BMI performance in all BSC perspectives can be categorized as good performance. The contribution of financial perspective is $19 \%$ and customer perspective contribution is $36 \%$. Meanwhile, the contribution of internal business process perspectives is $24 \%$ and the contribution of learning and growth perspective is $21 \%$. The performance with the lowest contribution is derived from the financial perspective. 
BMI management positions the financial perspective as a reporting and is an integral result of achieving the other three performance perspectives. However, the achievement of financial perspective targets can be categorized as good performance (91\%).

Performance measurement of BMI provides a description of the translation of the company's vision and mission into more operational actions. In this case, the performance measure can be the outcome and driver measures. From a financial perspective, the company sets the efficiency of operating costs, increasing revenue and increasing profits, and decreasing FDR as its strategic targets. The company seeks to improve financial performance doubled in the long run. The efficiency of operating costs and decreasing FDR allow companies to be able to manage their finances in a better way that leads to increased profits. The increase in revenue in the form of an increase in DPK and an increase in market share leads to an increase in operating income for the company, especially interest income which will affect the profits earned by the company. Achievement in the financial perspective is the result of achieving the other three perspectives because of its function as reported the effectiveness of its strategic objectives in the form of financial ratios (ROA, BOPO and LDR).

The customer perspective has a strategic objectives in term of increasing the debtors and customers satisfaction, deepening potential customers, increasing the number of customers, increasing the number of debtors, maintaining customer loyalty and appropriate categorization of debtors which refers more to the marketing process undertaken by the company. BMI has determined that customer value is a major factor in business, so the company strives to provide the best service to customers and debtors, both physical and non-physical services. This is consistent with BMI's brand image and positioning as a pioneer in housing finance. The segmentation of housing finance has also been expanded by procuring Platinum KPR credit products for the upper middle class. Thus, BMI is ready to face competition from similar companies.

Strategic objectives of the perspective of internal business processes are more directed at improving service quality, operating process efficiency and increasing reliability. In this perspective it is more directed to the operational processes carried out by the company in supporting the increase in customer value for the company. Physical facilities can include the provision of ATM machines in strategic locations and information boards on product interest rates. Non-physical facilities in the form of cleanliness and comfort of the waiting room, friendliness and courtesy of employees. Learning and growth perspectives include increasing employee satisfaction and motivation, increasing expertise and experience as well as technological and information reliability, which refers more to the management of human resources and technology properly. Satisfied employees will always support the company's goals as well as increase professionalism through the training held by BMI. The employee performance appraisal process is carried out every year to evaluate the extent of performance given by employees to the company in accordance with company standards. Technology and information have a function as the main complement in describing the professionalism of the company and the image embedded in the community that affects customer confidence in the bank.

\section{References}

Aslam, M.N.W., Marimin. Fahmi, I., Beik, I.S. (2016), "How Islamic is Islamic Banking in Indonesia?", JKAU: Islamic Economics, 29 (2), 153-165

Atkinson, H. (2006), "Strategy implementation: a role for the balanced scorecard?" Management Decision, 44(10), $1441-1460$

Chavan, M. (2009), "The balanced scorecard: a new challenge", Journal of Management Development, 28(5), 393-406

Fitriasari, F. (2012), "The Growth of Islamic Banking in Indonesia”, Ekonomika-Bisnis, 3 (1), 1-12

Heavey, C., and Murphy, E. (2012), "Integrating the Balanced Scorecard with Six Sigma", The TQM Journal, 24 (2), 108-122.

Hudson, M., Smart, A., and Bourne, M. (2001), "Theory and practice in SME performance measurement systems", International Journal of Operations \& Production Management, 21(8), 1096-1115

Iman, F.A.N., and Widodo, A. (2016), "Penilaian Kinerja Keuangan PT. Bank Muamalat Indonesia, Tbk Dengan Metode Economic Value Added", Ekonomika-Bisnis, 7 (1), 15-22

Jusoh, R., Ibrahim, D.N., and Zainuddin, Y. (2007), "Moderating Effect of Balanced Scorecard Measures Usage on Strategy-performance Relationship: An Empirical Study of Manufacturing Firms", Journal of Financial Reporting and Accounting, 5 (1), 87-118

Kaplan, R.S. (2012), “The balanced scorecard: comments on balanced scorecard commentaries", Journal of Accounting \& Organizational Change, 8(4), 539-545

Kaplan, R.S., and Norton, D.P. (1992), "The balanced scorecard: measures that drive performance", Harvard Business Review, 70 (1), 71-79

Kaplan, R.S., and Norton, D.P. (1996), "Linking the balanced scorecard to strategy", California Management Review, 39 (1), pp. 53-79

Kaplan, R.S., and Norton, D.P. (2001), "Transforming the balanced scorecard from performance measurement to 
strategic management: Part I", Accounting Horizons, 15 (1), 87-104

Manville, G. (2007), "Implementing a balanced scorecard framework in a not for profit SME", International Journal of Productivity and Performance Management, 56 (2), 162-169

Mariyono, J. (2013), "Determinants of Customers in Selecting Sharia Banking System for Saving In East Java Indonesia", Journal of Economics, Business, and Accountancy Ventura, 16 (3), 457 - 472

Ratnasingam, P. (2009), "Service quality management applying the balanced scorecard: an exploratory study", International Journal of Commerce and Management, 19 (2), 127-136

Sainaghi, R., Phillips, P., and Corti, V. (2013), "Measuring hotel performance: Using a balanced scorecard perspectives' approach", International Journal of Hospitality Management, 34, 150-159

Sari, M.D., Bahari, Z., Hamat, Z. (2016), "History of Islamic Bank in Indonesia: Issues behind Its Establishment", International Journal of Finance and Banking Research, 2 (5), 178-184

Sim, K.L., and Koh, H.C. (2001), "Balanced scorecard: a rising trend in strategic performance measurement", Measuring Business Excellence, 5 (2), 18-27

Tampubolon, N. (2015), "Roadmap of Indonesian Islamic Banking 2015 - 2019", retrieved from https://www.ojk.go.id/en/Documents/Pages/Islamic-Finance-OJK-2015/1.nelson.pdf

Wong, F.W.H., Lam, P.T.I., and Chan, E.H.W. (2009), "Optimising design objectives using the Balanced Scorecard approach", Design Studies, 30(4), 369-392

Zahoor, A., and Sahaf, M.A. (2018), "Investigating causal linkages in the balanced scorecard: an Indian perspective", International Journal of Bank Marketing, 36 (1), 184-207 